\title{
Effect of Leadership on Employee's Performance Mediated by Cultural Organization, Work Commitment and Motivation
}

\author{
Syahruddin Sappe, Yohanis Rante, Ruben Tuhumena, Bonifasia Elita Bharanti \\ University of Cendrawasih, Indonesia \\ ebonifasia@yahoo.com
}

\begin{abstract}
Main mission of regional autonomy is intended to improve the quality of public services and the welfare of the community, creating efficiency and effectiveness of human resource management, as well as empowering and creating a space for people to participate actively in the development process. Therefore, it needs a leader who act can generate commitment, motivation and optimism in carrying out the work, foster an atmosphere of cooperation, and can affect the behavior of subordinates who have an impact on improving the performance of employees. This study aims to identify and assess the relevance of leadership on employee performance mediated by organizational culture, work commitment and work motivation as determinants of employee performance improvement. The sample used in this study was 160 respondents to the analysis unit employees in Food Security Council Keerom Papua Province. Data was collected by questionnaires followed by in-depth interviews. Quantitative Data Analysis using Structural Equation Modeling (SEM) with the help of the program Analysis Moment Structures (AMOS). The results of this study indicate that, good leadership can improve employee performance, when considering the factors that come into play that organizational culture, work commitment and motivation work to DKP in Keerom Papua Province. Furthermore, the results of this study that the strengthening of organizational culture and high employee commitment can lead to increased motivation.
\end{abstract}

Keywords: Leadership, organizational culture, job commitment, work motivation and performance of employees

\section{Introduction}

Regional Autonomy policy implemented based on the Law of the Republic of Indonesia Number 22 of 1999 and No. 32 of 2004 on Regional Government which resulted in a fundamental shift in the role of State positions are centralized to decentralize. Observing this that the main mission of regional autonomy for the purpose of increasing the quality of public services and social welfare, create efficiency and effectiveness of human resource management, as well as empowering and creating a space for people to participate actively in the development process. The carrying capacity of the benefit when the wheels of government are managed and executed by a leader who can be the inspiration to encourage employee motivation through organizational culture and employee commitment, so as to improve performance (Alisyahbana, 2008). Lusiana and Abdullah (2009) states that the level of commitment and loyalty of employees Indonesia is still relatively low, even $22 \%$ lower than 10 other countries of Asian countries, and the results of a study of 8,000 respondents from 46 public sector organizations in Indonesia, the leadership is still low because employees assess do not receive adequate career development direction of its leader (Sutikno, 2007).

Some phenomena in the era of regional autonomy; first: lack of competency of the leader, it cannot be separated from the pattern of the campaign did not consider the competence of leaders to be lifted; second: the leader in running the organization has not been driven by the vision and mission of the organization; third: leaders rely on authority its formal, power used force in moving the employees, leaders do not understand the differences in the characteristics that belongs to the employees; and fourth: the policy over the task that is too often done great potential to give birth to leaders (officers) that are based on orders that are not professional career. Regional development is carried out through the development of regional autonomy and control of resources that provide opportunities for the realization of good governance, so as to create an environment that allows people to enjoy the quality of life better, progressive, peaceful, and simultaneously expand the choice that can be made public for increased dignity, dignity, and self-esteem, as 
prioritized in regional development in Papua. Observing this, the one issue that needs serious handling of decentralization is the issue of food security because it involves the sustainability of a region or country for the life of the next generation. The vulnerability of food security conditions lately, have slowed the development process in the region in particular and in general national.

In line with the Law Decree No. 32 of 2004 in the regional autonomy era has brought changes in the handling of national food security in Papua. The role of government in an effort to promote food security carried out by the Food Security Council (DKP) Papua in various ways such as strengthening the economic structure of society-based agribusiness and increase the role as well as local NGOs, a policy diversification that can strengthen food security, and the protection of agricultural land sustainable food, Through the handling of food security programs in the regional autonomy era where the role of the leader plays an important role. Handling of food security on an ongoing basis and continually driven by government Keerom Regency Papua Province through the Food Security Council in accordance Regent Decree Keerom Number 130 of 2014 concerning DKP as an institution that embodies technical SKPD in this area, namely: (1) the Department of Agriculture, Animal Husbandry and Fisheries Keerom, (2) Department of Forestry Plantations Keerom, (3) Education Executive Agency of Agriculture, Fisheries and Forestry Keerom, and (4) the Department of Cooperatives, Industry and Trade Keerom. Based on the phenomenon exists on Food Security Council in this area, obtained by the fact that it still encountered some kind of commodity food security is still imported from outside the region, one of which is rice which is the staple food. This phenomenon is contrary to the existing situation in which the vast and fertile landscape; on the other hand, rice is still imported from outside the region. It needs to be examined in depth of pengelolah areas that help local leaders in food availability. In connection with the fact that we can observe, that the civil servants who exist in this Food Security Council in carrying out a duty not optimal.

Not optimal performance of employees in the work unit, so that the quality of human resources is important to be studied, it has an impact on the need for efforts to develop human resources as one of the essential competencies of the organization to face the current era of globalization which confronted us of the challenges that are complex, including how the food security policy of regional or national in meeting the food needs of people at any time in the right quantity and quality. The importance of leadership problems, make the leader has always been a focus of the evaluation of the causes of success or failure of an organization. The same thing also supported the opinion Schein (1992) states that the leader has a great influence on the success of the organization in the face of emerging challenges. Among the management theories that exist, one of which is a model Primal Leadership, which builds upon the leadership model to do with neurology, research on the brain, indicate why the mood and actions have a major impact on the employees they lead. This discovery provides a new framework that an intelligent leader in terms of emotion to inspire, excite and antutisme and keep people motivated and committed in carrying out the work and foster an atmosphere of cooperation, passion and can affect the behavior of subordinates based on values which are owned to an end organization (Goleman et al., 2004).

Intelligent leadership in terms of emotion will bring authority and consequently bring in a good performance. Leaders have the power to toying with the emotions of each employee. If employees are encouraged towards atusiasme emotion, the performance will increase and vice versa if the employee emotionally driven towards hatred and anxiety will decrease performance (Goleman et al., 2004). From the results of previous research found that, a leadership role in improving the performance of the role of organizational culture, work commitment and work motivation. Leadership is an important variable in strengthening the organizational culture in an organization. From the research found that the leadership's positive effect on organizational culture (Xenikou and Simosi, 2006; Kuchinke, 2004). Similarly, leadership and organizational culture have a synergy effect on performance (Amran and Kusbramayanti, 2007; Tsang, 2007). Besides, there is a significant positive relationship between leadership and performance (Goleman et al., 2004; Carmeli, 2006).

Gibson (1996) further explores the relationship between leadership and work commitments which concluded that employees who are empowered by the leader will be committed to the organization. Leadership and work commitments have a synergy effect on employee performance. Carmeli (2006) states that the leaders who have a high responsibility and attention will impact the high commitment. Similarly Gilder (2003) concluded that a high work commitment to be a positive influence on employee performance. Herzberg in 
Siagian (2004), the inventor of the two-factor theory of motivation, that job satisfaction is derived from the existence of intrinsic motivators (such as progress, knowledge, work, and responsibility). Explained further, that job dissatisfaction is derived from the absence of extrinsic factors (such as working conditions, wages, personal relationships, supervision, and organizational policies). Strategies to motivate employees should still be considered as a determining factor of success of the organization. Leaders who can motivate their employees will result in improved performance. This is in line with the findings of Porter et al. (1974) that the leadership with a high degree of maturity will have a positive impact on work motivation. Furthermore, leadership and high employee motivation have a synergy effect on employee performance. Based on the interrelationship between variables research, research conceptual framework can be built as in the picture below.

Figure: 1 Concept Framework Research

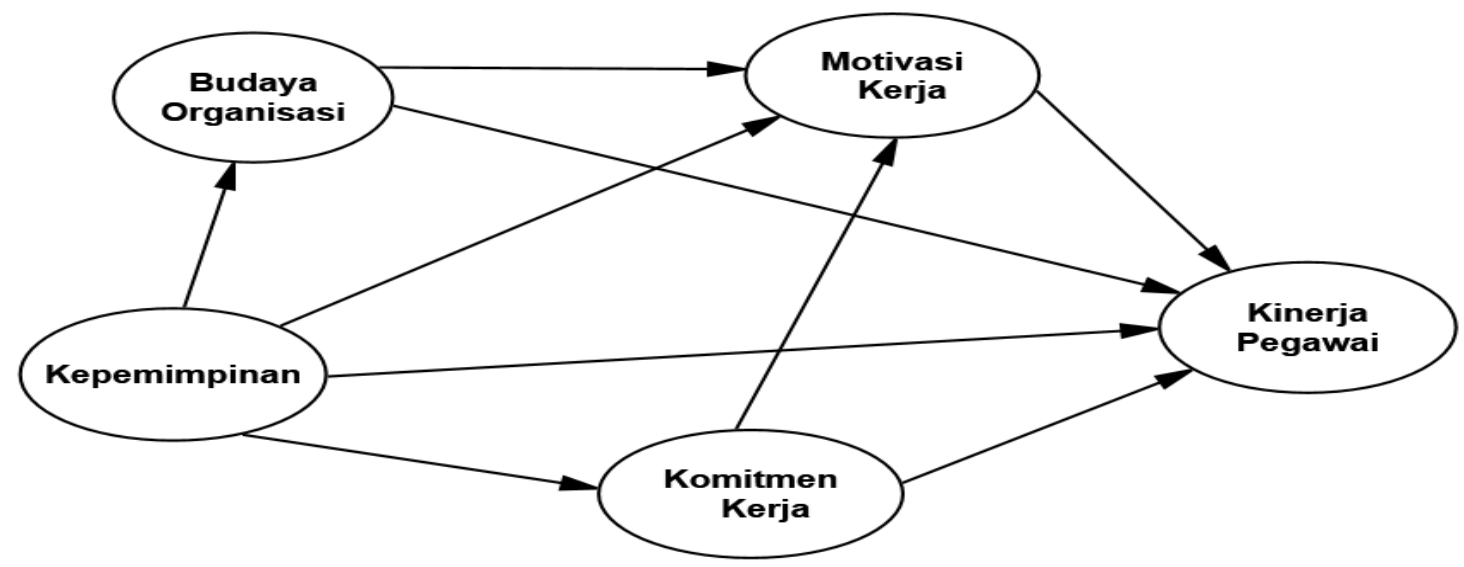

\section{Methodology}

The approach of this research is a quantitative approach (positivism). This quantitative approach, is to conduct a survey technique is a study that takes a sample of a population to rely on a questionnaire as data collection instruments, to obtain information and facts in a factual and generally the unit of analysis is the individual (Singarimbun and Effendi, 1995). This study proposed to examine and analyze the influence of leadership on employee performance mediated by organizational culture, work commitment and work motivation. This research is explanatory, which is a study that aims to find an explanation for the causal relationship or influence the relationship between variables with other variables, and test hypotheses (Singarimbun and Effendi, 1995). Research was conducted on Food Security Council Keerom Regency Papua province. The population in this research is the overall government employees on Food Security Council Keerom as many as 267 people. Determination of the number of samples is done by using the formula Slovin (Umar, 2001). Collecting data in this study done in two ways: (a) the deployment of a list of questions (questionnaire), and (b) in-depth interviews. The method of measurement used is Likert Scale, to measure attitudes to agree or disagree on the subject, object or certain events. The data analysis used in this research is Structural Equation Modeling (SEM). SEM methods used to analyze the causal relationship between variables defined in this study either directly (direct effects) or indirectly (indirect effects) Ferdinand (2005).

\section{Results and Discussion}

Results of SEM analysis of the relationship between the constructs (latent variables) overall in the final stages of the model indices modification, as in the picture below. 
Figure 2: Results Model

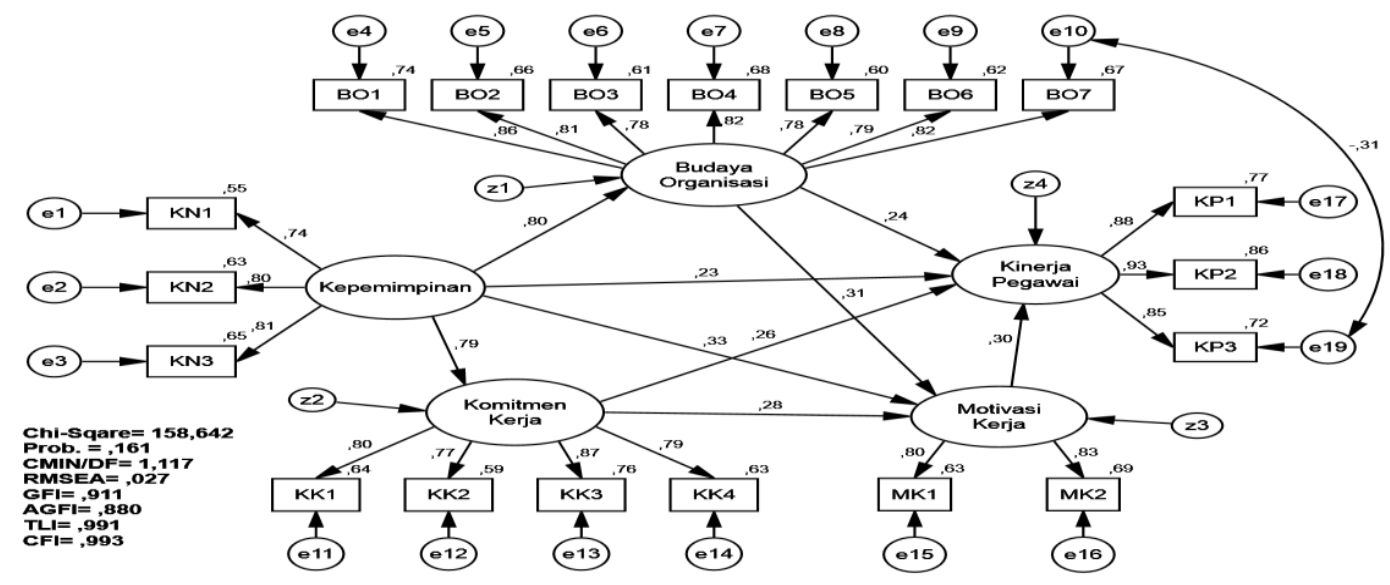

The test results construct the research model presented in Figure 2 were evaluated based on goodness of fit indices, as in the following table.

Table 1: Evaluation Goodness of Fit Indices Model

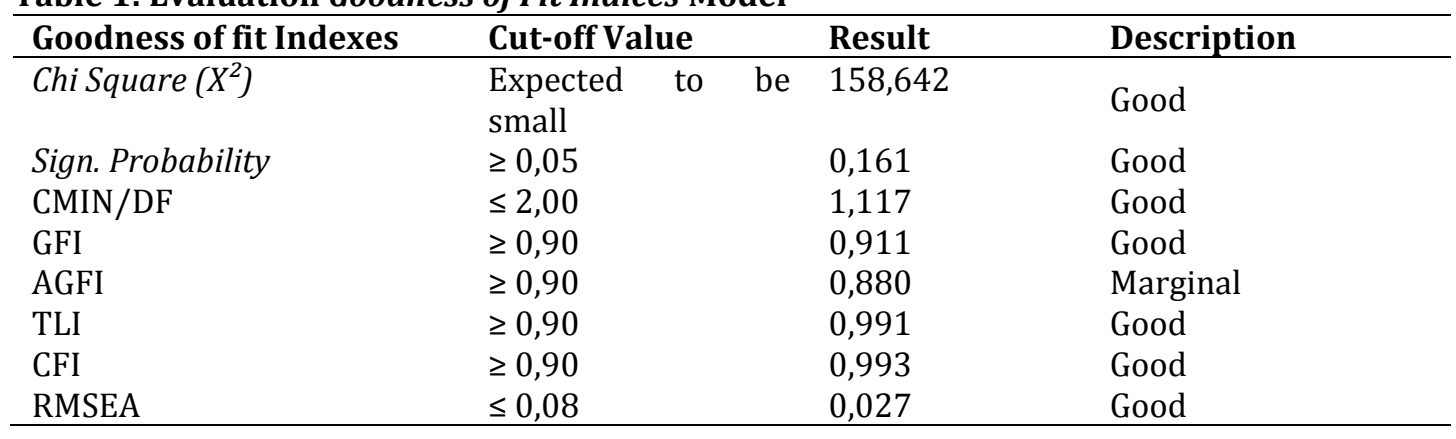

Table 1 show that the model can be accepted evidenced by the value of the model that has been required of the cut-of value, so that the data can be further tested to determine how much the estimated value of each of the variables. Next, test the influence of the constructs that influence directly (direct effects) and the influence indirectly (indirect effects). The direct effect and indirect effect can be seen in the following table.

Table 2: Path Coefficient Testing

\begin{tabular}{|c|c|c|c|c|c|c|c|}
\hline \multirow[b]{2}{*}{$\begin{array}{l}\text { Independent } \\
\text { variable }\end{array}$} & \multirow[b]{2}{*}{$\begin{array}{l}\text { Dependent } \\
\text { variables }\end{array}$} & \multicolumn{2}{|c|}{ Influence } & \multirow[b]{2}{*}{ Total } & \multirow[b]{2}{*}{ CR } & \multirow[b]{2}{*}{ P-Value } & \multirow[b]{2}{*}{ Decision } \\
\hline & & Direct & Indirect & & & & \\
\hline Leadership & $\begin{array}{l}\text { Organizational } \\
\text { culture }\end{array}$ & 0,803 & 0,000 & 0,803 & 9,154 & 0,000 & Accepted \\
\hline Leadership & $\begin{array}{l}\text { Work } \\
\text { Commitment }\end{array}$ & 0,791 & 0,000 & 0,791 & 8,485 & 0,000 & Accepted \\
\hline Leadership & $\begin{array}{l}\text { Work } \\
\text { motivation }\end{array}$ & 0,334 & 0,475 & 0,809 & 2,014 & 0,044 & Accepted \\
\hline Leadership & $\begin{array}{l}\text { Employee } \\
\text { Performance }\end{array}$ & 0,226 & 0,640 & 0866 & 1,807 & 0,071 & Rejected \\
\hline $\begin{array}{l}\text { Organizational } \\
\text { culture }\end{array}$ & $\begin{array}{l}\text { Work } \\
\text { motivation }\end{array}$ & 0,313 & 0,000 & 0,313 & 2,474 & 0,013 & Accepted \\
\hline $\begin{array}{l}\text { Organizational } \\
\text { culture }\end{array}$ & $\begin{array}{l}\text { Employee } \\
\text { Performance }\end{array}$ & 0,238 & 0,093 & 0,331 & 2,540 & 0,011 & Accepted \\
\hline $\begin{array}{l}\text { Work } \\
\text { Commitment }\end{array}$ & $\begin{array}{l}\text { Work } \\
\text { motivation }\end{array}$ & 0,282 & 0,000 & 0,282 & 2,141 & 0,032 & Accepted \\
\hline
\end{tabular}




\begin{tabular}{|c|c|c|c|c|c|c|c|}
\hline $\begin{array}{l}\text { Work } \\
\text { Commitment }\end{array}$ & $\begin{array}{l}\text { Employee } \\
\text { Performance }\end{array}$ & 0,262 & 0,084 & 0,346 & 2,765 & 0,006 & Accepted \\
\hline $\begin{array}{l}\text { Work } \\
\text { motivation }\end{array}$ & $\begin{array}{l}\text { Employee } \\
\text { Performance }\end{array}$ & 0,299 & 0,000 & 0,299 & 2,553 & 0,011 & Accepted \\
\hline
\end{tabular}

Table 2 shows that leadership have direct positive effect on the organizational culture of 0.803 or $80.30 \%$, direct positive influence on work commitment 0.791 or $79.10 \%$, direct positive influence on work motivation of 0.334 or $33.40 \%$, and indirectly through organizational culture and work commitments have positive influence on work motivation of 0.475 or $47.50 \%$, direct influence on the performance of employees amounted to 0.226 or $22.60 \%$ not significant, and indirectly through organizational culture, work commitments and work motivation positive effect on the performance of employees amounted to 0.640 or $64.00 \%$. Furthermore, the organizational culture is directly positive effect on work motivation at 0,313 or $31.30 \%$, direct positive effect on the performance of employees amounted to 0.238 or $23.80 \%$, and indirectly through work motivation positive effect on the performance of employees amounted to 0.093 or $9,30 \%$. While the commitment to work directly positive effect on employee motivation by 0,282 or $28.20 \%$, direct positive effect on the performance of employees amounted to 0.262 or $26.20 \%$, and indirectly through work motivation positive effect on the performance of employees amounted to 0,084 , or $8,40 \%$. Motivation to work directly positive effect on the performance of employees amounted to 0,299 , or $29.90 \%$. Based on the statistical analysis of the results obtained by the model end of the study as follows:

\section{Figure 3: Model Final Research Findings}

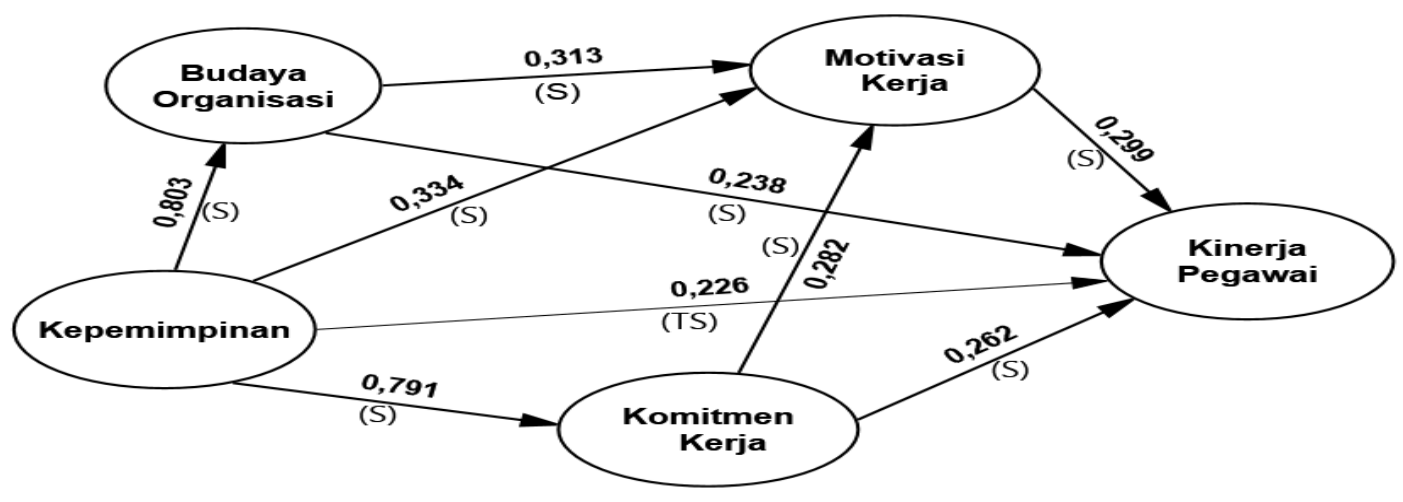

Description: (S) significantly, (TS) not significant

Model final findings above imply the following. Leadership effect on employee performance through organizational culture, work commitment and work motivation. Therefore it can be explained that the leadership has a value of self-awareness, social awareness and self-management, can improve employee performance in the form of quantity, quality d's time, if the notice of organizational culture, work commitment and work motivation. So the influence of leadership on employee performance through organizational culture, work commitment and work motivation effect meaningful and full of character as an intervening variable. Thus the organizational culture, work commitment and work motivation capable of mediating leadership with employee performance. This reinforces the opinion of Goleman et al., (2004) that a leader is able to generate the commitment, motivation, optimism in carrying out the work as well as foster an atmosphere of cooperation, a passion that can affect the behavior of subordinates to achieve organizational goals.

Leadership effect on work motivation, either directly or indirectly through organizational culture and work commitments. Therefore it can be explained that the leadership has a value of self-awareness, social awareness and self-management, can improve employee motivation that is the impetus arising from the employees themselves. Therefore, the influence of leadership on work motivation through organizational culture and commitment to effect meaningful work and are fully intervening. This reinforces the theory which states that a leader must know the character (traits, behaviors, skills and knowledge) every employee; every 
employee is different character with the character of other employees. By knowing the character of each employee, then the leader can determine the motivation for each employee (Siagian, 2004). The same is stated by Herzberg that only challenging work that motivates employees. Organizational culture influence on employee performance directly and indirectly through work motivation. Therefore it can be explained that a strong organizational culture that will trigger a high motivation to work, so it will improve the performance of employees. Strong organizational culture can be interpreted that the employees who work with innovation and risk-taking as well as attention to detail things that would be able to trigger the intrinsic motivation which is the driving force arising from within the employees of the organization will result in better quality work. This reinforces the opinion of Schein (1992) that organizational culture will motivate employees to cooperate productively managed to achieve and realize the goals set.

Commitment affects the work performance of employees, either directly or indirectly through work motivation. Therefore it can be explained that the improvement in the high work commitment will trigger a high motivation to work anyway, so it will improve the performance of employees. High work commitment characterized by high confidence and loyalty, will be able to trigger the intrinsic motivation which is the driving force arising from within the employees of the organization will result in better quality work. This reinforces the idea Luthans (1996), that the individual commitments are demonstrated through her involvement in the organization, in particular believing or trusting the goals and values of the organization, assist businesses in achieving organizational goals. Strengthen two-factor theory of Herzberg in Siagian (2004) that an individual's relationship with his work is fundamental and therefore a person's attitude towards work is very likely determine the success and failure.

Implications Research: Results of this study could build a theoretical model on the influence of leadership on employee performance mediated by organizational culture, work commitment and work motivation. This model is also able to explain that the influence of leadership directly to employee performance is not significant, but the leadership is indirectly influence on employee performance through organizational culture, work commitment and work motivation effect meaningful and full of character as an intervening variable (fully intervening). Thus the organizational culture, work commitment and work motivation capable of mediating leadership with employee performance. It gives the sense that the leader is not necessarily directly affect the performance of employees but there needs to be strengthening the organizational culture and work commitment and work motivation is high because there is a predictor in improving employee performance.

Limitations Research: The object of research is limited to Food Security Council Keerom Regency Papua Province, so that these results can not necessarily be generalized to other regions that have different characteristics. In this study, observations were made using the time coverage is cross section which means that the data derived from a certain time, while the behavior of leaders and impact the performance of employees at other times (time series) are not included in this study.

\section{Conclusion}

Leadership role improving employee performance through cultural organizational, work commitment and work motivation. This indicates that the leadership has a high self-management which is capable of forming a strong organizational culture, and can improve work commitment and work motivation. Strong organizational culture is reflected by working in an innovative and willing to take risks with their attention to matters of detail. High work commitment is reflected by having high confidence and loyalty to the organization. While the high motivation reflected by intrinsic motivation is able to mediate a leadership role in improving employee performance. Strengthening the organizational culture a culture of innovation and risk-taking with an attention to detail matters, the role increases the motivation and performance of employees. High work commitment which has high confidence and loyalty to the organization served to increase motivation and performance of employees. High motivation that is intrinsic motivation because of the impetus arising from within the employee plays a role in improving employee performance that is improving the quality of work. 
Suggestions: The leader should have a sense of empathy, that is able to understand what is wanted and needed by the employee in this case a leader is able to meet the expectations of employees. Leaders must reevaluate the competence of employees based on their level of education and skills possessed because not all employees have the same ability. Further research could develop this research to reexamine the consistency of the results of this research to develop models and other variables, such as the nature or leadership style associated with the local culture in increased motivation and performance.

\section{References}

Alisyahbana. (2008). Makalah disampaikan pada: Seminar Nasional solusi dan Evaluasi Krisis Masa Depan Ekonomi Nasional. Yang diselenggarakan Jurusan Ekonomi dan Studi Pembangunan Fakultas Ekonomi Universitas Pasundan Bandung 20 Juli 2008.

Amran, T. G. \& Kusbramayanti, P. (2007). Leadership and Organizational Culture Relationship Analysis on Job Performance and Satisfaction Using SEM at Carita Boat Indonesia. Proceeding, International Seminar on Industrial Engineering and Management. Menara Peninsula, Jakarta. August 29-30.

Carmeli, A. (2006). The Relationship between Emotional Intelligence and work attitude, Behavior and Outcomes. An Examination among Senior Manager. Journal of Managerial Psychology, 18(8), 788-813.

Ferdinand, A. (2005). Structural Equation Modeling dalam Penelitian Manajemen. Edisi Ketiga. Semarang: BP Undip.

Gibson. (1996). Organisasi Edisi ke-8. Jakarta: Jembatan.

Gilder, D. (2003). Commitment, Trust and Work Behavior. The Cases of Contingent Workers. Personnel Review, 32(5), 588-604.

Goleman, D., Boyatzis, R. \& Mckee, A. (2004). Primal Leadership (Kepemimpinan Berdasarkan Kecerdasan Emosi). Jakarta: PT Gramedia Pustaka Umum.

Kuchinke, K. P. (2004). Leadership and culture: Work-Related Values and Leadership style's Among One Company's US and German Telecommunication Employees. Human Resources Development Quarterly, $10(2), 135-152$.

Lusiana. \& Abdullah. (2009). Pengaruh Komitmen Terhadap Kepuasan Kerja: Motivasi sebagai Variable Intervening. Bandung: Fakultas Ekonomi UNIB.

Luthans, F. (1996). Organizational Behavior. Singapore: McGraw Hill Book Company.

Porter, L. W., Steers, R. M., Mowday, R. T. \& Boulian, P. V. (1974). Organizational Commitment, Job Satisfaction, and Turnover among Psychiatric Technicians. Journal of Applied Psychology, 59, 603-609.

Schein, E. H. (1992). Organizational Culture and Leadership. San Fransisco: Jossey-Bass Publisher.

Siagian, S. P. (2004). Teori Motivasi dan Aplikasinya. Jakarta: PT. Rineka Cipta.

Singarimbun, M. \& Effendi, S. (1995). Metode Penelitian Survey. Jakarta: LP3ES

Sutikno, R. B. (2007). The Power of Empathy in Leadership (Mengoptimalkan Performan Karyawan dengan Prinsip Empati). Jakarta: PT Gramedia Pustaka Umum.

Tsang, D. (2007). Leadership, National Culture and Performance Management in the Chinese Software Industry. International Journal of Productivity and Performance Management, 56(4), 270-284.

Umar, H. (2001). Riset Sumber Daya Manusia. Jakarta: Gramedia Pustaka.

Xenikou, A. \& Simosi, M. (2006). Organizational Culture and Transformational Leadership as Predictor of Business Unit Performance. Journal of management Psychology, 21(26), 566-579. 